\title{
Effects of Stress Waves on Cells
}

\author{
H.L. Campbell, S.R. Visuri, L.B. Da Silva
}

This paper was prepared for submittal to the Laser Tissue Interaction IX Conference

San Jose, CA, January 24-30, 1998

\section{March 2, 1998}

U.S. Department of Energy

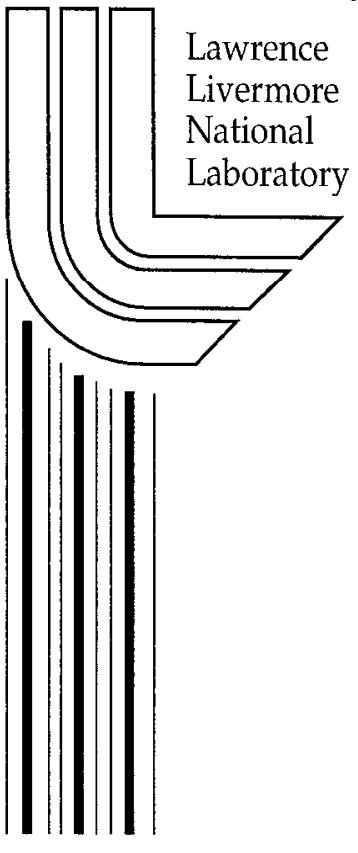




\section{DISCLAIMER}

This document was prepared as an account of work sponsored by an agency of the United States Government. Neither the United States Government nor the University of California nor any of their employees, makes any warranty, express or implied, or assumes any legal liability or responsibility for the accuracy, completeness, or usefulness of any information, apparatus, product, or process disclosed, or represents that its use would not infringe privately owned rights. Reference herein to any specific commercial product, process, or service by trade name, trademark, manufacturer, or otherwise, does not necessarily constitute or imply its endorsement, recommendation, or favoring by the United States Government or the University of California. The views and opinions of authors expressed herein do not necessarily state or reflect those of the United States Government or the University of California, and shall not be used for advertising or product endorsement purposes.

This is a preprint of a paper intended for publication in a journal or proceedings. Since changes may be made before publication, this preprint is made available with the understanding that it will not be cited or reproduced without the permission of the author.

This report has been reproduced

directly from the best available copy.

Available to DOE and DOE contractors from the

Office of Scientific and Technical Information

P.O. Box 62, Oak Ridge, TN 37831

Prices available from (423) 576-8401

http://apollo.osti.gov/bridge/

Available to the public from the

National Technical Information Service

U.S. Department of Commerce

5285 Port Royal Rd.,

Springfield, VA 22161

http://www.ntis.gov/

OR

Lawrence Livermore National Laboratory

Technical Information Department's Digital Library

http://www.llnl.gov/tid/Library.html 


\title{
Effects of Stress Waves on Cells
}

\author{
Heather L. Campbell, Steven R. Visuri, Luiz B. Da Silva \\ Lawrence Livermore National Laboratories \\ Livermore, CA 94551
}

\begin{abstract}
Laser induced stress waves are being used in a variety of medical applications, including drug delivery and targeted tissue disruption. Stress waves can also be an undesirable side effect in laser procedures such as ophthalmology and angioplasty. Thus, a study of the effects of stress waves on a cellular level is useful. Thermoelastic stress waves were produced using a Q-switched frequency-doubled Nd:YAG laser $(\lambda=532 \mathrm{~nm})$ with a pulse duration of $4 \mathrm{~ns}$. The laser radiation was delivered to an absorbing media. A thermoelastic stress wave was produced in the absorbing media and propagated into plated cells. The energy per pulse delivered to a sample and the spot size were varied. Stress waves were quantified. We assayed for cell viability and damage using two methods. The laser parameters within which cells maintain viability were investigated and thresholds for cell damage were defined. A comparison of cell damage thresholds for different cell lines was made.
\end{abstract}

Key Words: stress wave, cell damage, photoacoustic

\section{INTRODUCTION}

Short pulse lasers are used in a number of clinical procedures, including lithotripsy, ophthalmology and drug delivery. Pressure transients produced by these short pulse lasers may produce damage to surrounding cells and tissues. Stress waves are produced when optical energy is absorbed into an appropriate medium. If the deposition of this energy is less than the stress confinement time, a wave is produced.

There has been some research done in this field previously, most notably at Wellman Laboratories of Photomcdicinc. They have used excimer lasers, with rise times from 10-25 ns in their experiments on stress waves and cell death. They have reported stresses up to kbars, though they have mainly published results on the compressive components of the waves. Fluences ranged from $90-560 \mathrm{~mJ} / \mathrm{cm}^{2}$. Their results were cell-type dependent. ${ }^{1}$

\section{MATERIALS AND METHODS}

Figure 1 shows the experimental arrangement. A slide coverslip with black enamel paint on the underside was placed onto a second coverslip. Water-based gel placed between the paint and glass assurcd good acoustic coupling. This second coverslip had cells plated on the underside. Stress waves were produced by the deposition of optical energy into the black paint, which is in turn vaporized, propagating a stress wave. The approximate distance between the absorption of the laser and the target cells was $450 \mu \mathrm{m}$. This experimental arrangement prevented any measurable temperature rise and optical energy to reach the cells. 


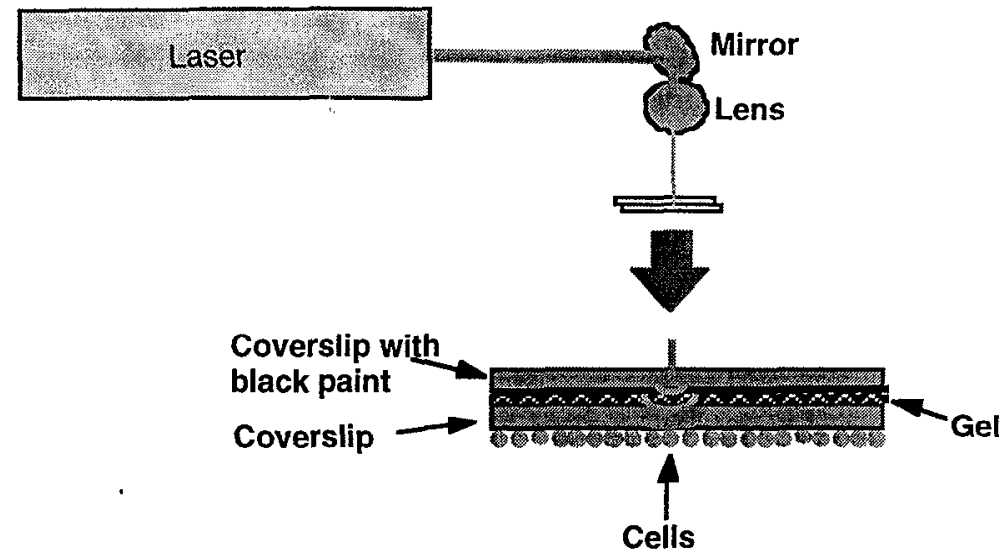

Figure 1. Experimental Set-up

The laser source was a Q-switched, frequency-doubled Nd:YAG laser (Spectra Physics, Mountain View, CA). The wavelength was $532 \mathrm{~nm}$ and the beam profile was Gaussian. Pulse duration was approximately $4 \mathrm{~ns}$. Energy per pulse was varied from $2.13 \mathrm{~mJ}$ to $217 \mathrm{~mJ}$, using neutral density filters. Spot size was also varied by focusing the beam and moving the target to discrete distances. Spot sizes obtained varied from $440 \mu \mathrm{m}$ to $2400 \mu \mathrm{m}$. as measured by photo-sensitive paper. Consequently, the fluence range was 226 $\mathrm{mJ} / \mathrm{cm}^{2}$ to $6060 \mathrm{~mJ} / \mathrm{cm}^{2}$.

We estimated the stress confinement time of our experimental arrangement to be $30 \mathrm{~ns}\left(\tau_{\mathrm{s}}=\mathrm{d} / \mathrm{c}_{\mathrm{s}}\right)$. This was calculated using a penetration depth, $d$, of $50 \mu \mathrm{m}$ and $1500 \mathrm{~m} / \mathrm{s}$ as the speed of sound, $\mathrm{c}_{\mathrm{s}}$, in our medium. Since the deposition of our energy occurred within $4 \mathrm{~ns}$, the energy was stress-confined.

The pressure magnitude in the stress waves was measured using a PVDF (polyvinylidene fluoride) hydrophone (NTR Systems, Seattle WA). The hydrophone has a relatively flat frequency response from 0$20 \mathrm{MHz}$ and the sensing area is $1 \mathrm{~mm}$ in diameter. Figure 2 shows a typical pressure profile obtained with the hydrophone. The hydrophone was placed at varying distances from the target and a plot of distance vs. pressure was obtained. 


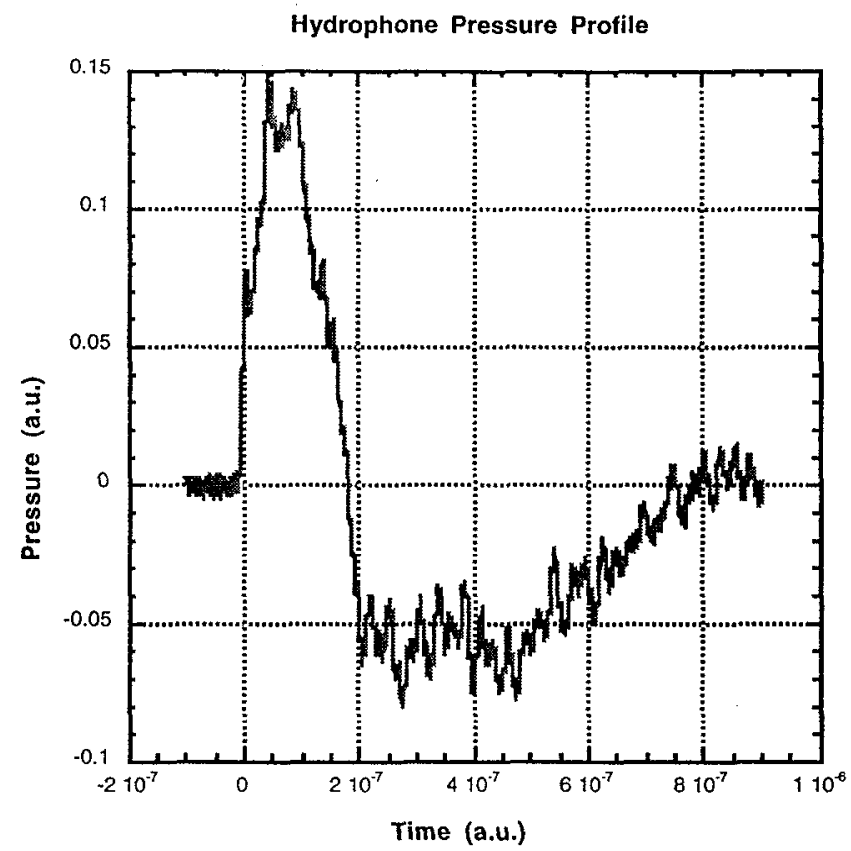

Figure 2. Pressure profile

Three different cell lines (ATCC, Rockville, MD) were used as targets: 769P (human renal adenocarcinoma), NCTC (mouse fibroblasts from connective tissue), and MES-SA (human uterine sarcoma). All cells were grown under standard cell culture techniques, in a $37^{\circ} \mathrm{C}, 5 \% \mathrm{CO}_{2}$ incubator. Cells were passed and plated onto slide coverslips that were coated with poly-L-lysine to promote adhesion. Cells were then placed back in the incubator, allowed to reach near-confluency and used as targets in the laser experiments.

After laser irradiation, cells were returned to the incubator for 12 hours and then were assayed for cell death using two methods: fluorescence microscopy and Trypan Blue. The fluorescence microscopy assay involved the use of the LIVE/DEAD Viability/Cytotoxicity kit (Molecular Probes, Eugene, OR), which is comprised of calcein-AM and ethidium homodimer-1, both of which fluoresce weakly in the media. Figure 3 shows the mechanism of the assay. The AM portion of the calcein-AM molecule facilitates transport across the plasma membrane. Once inside a live cell, the AM is cleaved by intracellular esterases and calcein becomes highly fluorescent (green). Ethidium homodimer-1 cannot enter cells through intact membranes. However, in a dead cell with a compromised membrane, ethidium homodimer- 1 enters the cell, binds to the DNA and increases its red fluorescence intensity 40-fold. Calcein-AM also enters the dead cell but the AM is not cleaved and it remains virtually non-fluorescent. A solution of $150 \mu \mathrm{l}$ of $4 \mu \mathrm{M}$ calceinAM and $4 \mu \mathrm{M}$ ethidium homodimer-1 was added to the coverslips and allowed to incubate at room temperature for 30 minutes. Coverslips were mounted on slides and observed under a fluorescent microscope (Zeiss). Trypan Blue staining was performed in the usual manner. Trypan Blue enters cells with compromised membranes and is unable to enter those with intact membranes. Both methods produced similar results. 


\section{Live Cell}

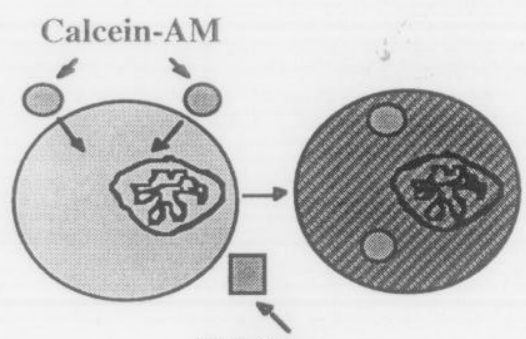

Ethidium

\section{Dead Cell}

\author{
Ethidium Homodimer-1
}

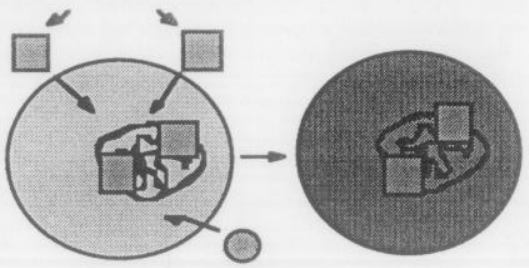

Calcein-AM

Homodimer-1

Figure 3. Fluorescence Microscopy Assay

\section{RESULTS}

The stress waves produced had both a positive (compression) and negative (tension) component. This results from reflections off of the glass-air interface. The magnitude of the tensile portion of the wave was approximately half the magnitude of the compression portion of the wave. Figure 4 shows the percent of samples demonstrating some degree of damage as a function of the fluence produced, for the NCTC target cells. The laser-treated samples are grouped according to average spot size. No damaged samples were observed at the smallest spot size $(560 \mu \mathrm{m})$, regardless of the resulting fluences $(1400,3480$, and 6060 $\mathrm{mJ} / \mathrm{cm}^{2}$ ). However, at the larger spot sizes, a positive correlation was observed between the fluence produced and the percent of samples that were damaged. For the largest average spot size $(2000 \mu \mathrm{m})$, there was no damage observed at the lowest fluences $\left(226\right.$ and $483 \mathrm{~mJ} / \mathrm{cm}^{2}$ ). Damaged samples were observed at the higher fluences $\left(701,913\right.$, and $\left.1200 \mathrm{~mJ} / \mathrm{cm}^{2}\right)$. For the medium average spot size $(960 \mu \mathrm{m})$, no damage was observed at the lowest fluence $(424 \mathrm{~mJ} / \mathrm{cm} 2)$, but damage was noted at 829,1180 , and $2590 \mathrm{~mJ} / \mathrm{cm}^{2}$. Figure 5 shows the correlation between fluences and the pressure differential at the distance from the target that the cells were placed. Damaged samples were observed at the two larger spot sizes between 200 bar and 400 bar. At approximately 400 bar, 100 percent of the samples were damaged. The $2000 \mu \mathrm{m}$ spot size had resulting pressures up to $554 \mathrm{bar}$, though damage peaked at $400 \mathrm{bar}$. The $960 \mu \mathrm{m}$ spot size had resulting pressures up to 432 bar. 


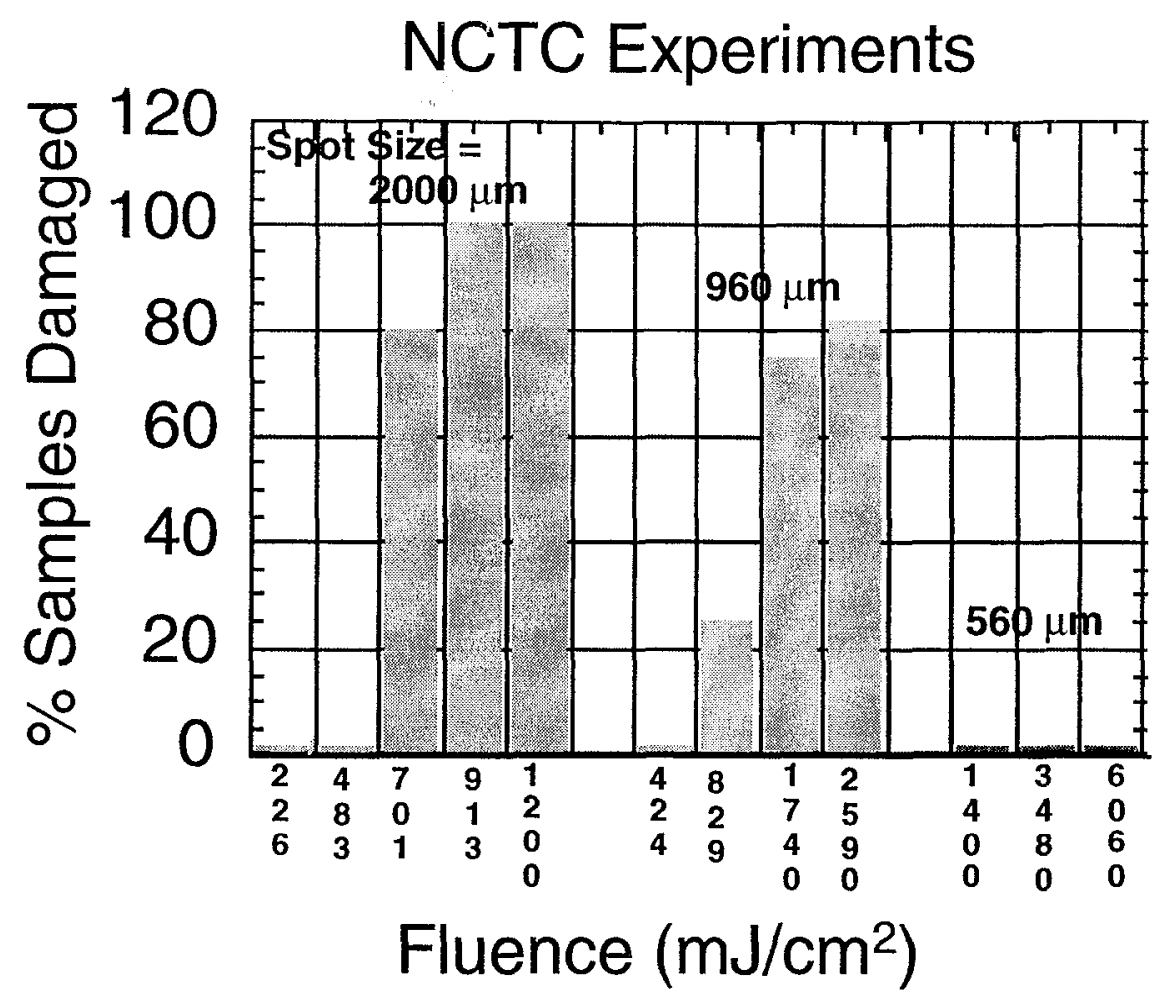

Figure 4. Fluence vs. \% Samples Damaged

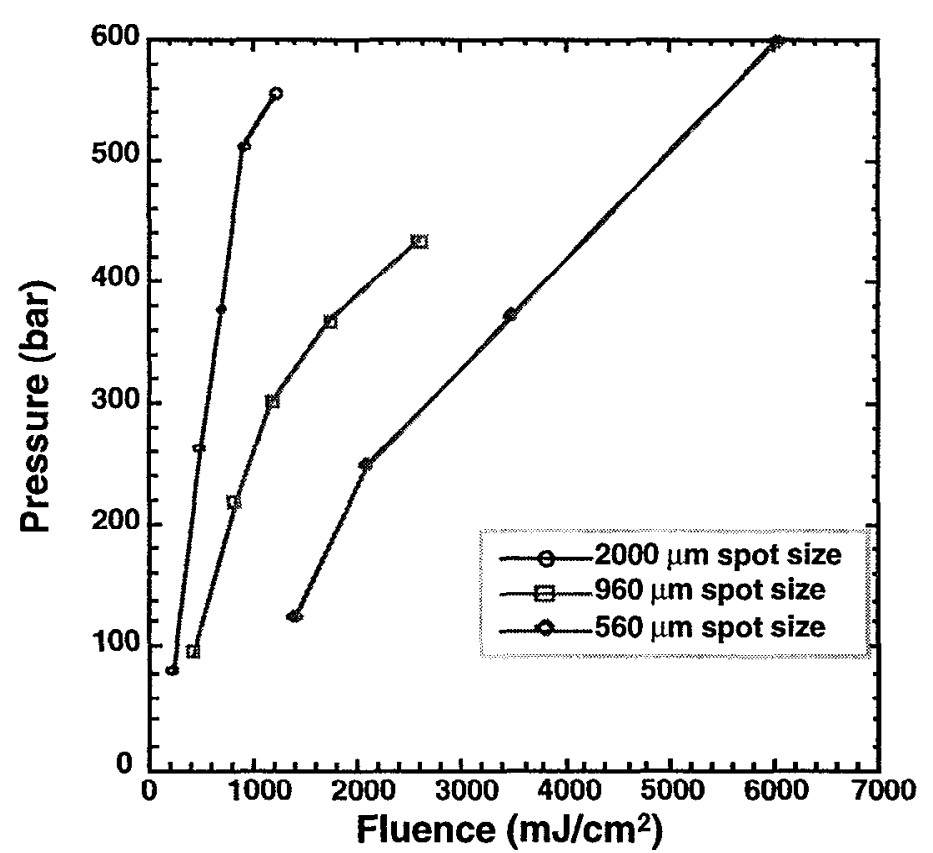

Figure 5. Fluence vs. Pressure at Cells

At times, we observed a hole in the cell layer, visible to the naked eye, immediately after laser treatment. In other instances, a hole was not observed immediately following treatment, but was observed during the cell death assays. A combination of two events may be happening. The cells may be knocked 
off the coverslip by the pressure of the stress waves. Alternatively, cells may be dying during the 12 hour incubation and floating off of the coverslip, resulting in a hole during the assay. Dead cells typically lose their adhesion to their substrate. The three cell lines used as targets had similar thresholds for damage.

\section{DISCUSSION}

We believe that spot size effects were responsible for the differences in damage that we observed. With a small spot size, the stress wave produced propagates in a spherical manner almost from the outset. The peak pressure in a spherical wave falls off in a $1 / \mathrm{r}$ manner. However, a larger spot size will initially produce a planar wave, in which the peak pressure falls off more slowly, in a linear fashion. This planar wave eventually evolves into a spherical wave, due to defraction, and the pressure begins to fall off at a rate of 1/r. This would account for the higher number of samples damaged with the larger spot sizes, and lower fluences, and the lack of damage observed at the smaller spot sizes. To prevent damage to the hydrophone, the proximity to the target was limited to $1 \mathrm{~mm}$. For the larger spot size, the pressure falls off at a rate close to $1 / \mathrm{r}$, whereas at closer than $2 \mathrm{~mm}$, the pressure seems to fall away at a linear rate. With the smaller spot size, the pressure falls off at a rate that closely approximates $1 / \mathrm{r}$.

The existence of a tensile component to the stress wave accounts for the differences between our results and those obtained at Wellman. The cell damage threshold for tensile waves has been found to be significantly lower than that for solely compressive waves. ${ }^{2}$ Our findings are relevant to fiber-delivered applications, in which the resulting stress waves have both a compressive and tensile component. Cavitation was probably also present in our experimental set-up. Water fails at approximately $10-100$ bar, negative component.

We intend to further quantify the cell death and damage observed, using assays to detect earlier stages of cell death than membrane integrity. In addition, temporal effects on cell damage, obtained by varying the incubation time post-treatment, will be explored. Obtaining data on the damage caused by the different components of the wave is also of interest. Spot size effects, multiple pulses, and pulse duration differences will be investigated.

\section{REFERENCES}

${ }^{1}$ Doukas, A.G., McAuliffe, D.J., Flotte, T.J., "Biological effects of laser-induced shock waves: structural and functional cell damage in vitro". Ultrasound in Medicine and Biology, 19(2): p. 137-146, 1993.

${ }^{2}$ Niemz, M.H., Lin, C.P., Pitsillides, C., Cui, J., Doukas, A.G., Deutsch, T.F., "Laser-induced generation of pure tensile stresses". Applied Physics, 70(20): p. 2676-2678, 1997.

\section{ACKNOWLEDGMENTS}

The authors wish to thank Jim Tucker and Marilyn Ramsey for their assistance with fluorescence microscopy.

This work was performed under the auspices of the U.S Department of Energy by Lawrence Livermore National Laboratory under Contract W-7405-Eng-48. 